\title{
Optimizing Breeding Decisions for Finnish Dairy Herds
}

\author{
By P. J. Rajala-Schultz ${ }^{l, 2}$, Y. T. Gröhn ${ }^{3}$ and H. G. Allore $^{3}$
}

${ }^{1}$ Department of Veterinary Preventive Medicine, College of Veterinary Medicine, The Ohio State University, Co-
lumbus, OH, USA, ${ }^{2}$ Department of Clinical Veterinary Sciences, Faculty of Veterinary Medicine, University of
Helsinki, Finland, ${ }^{3}$ Section of Epidemiology, Dept. of Population Medicine and Diagnostic Sciences, College of
Veterinary Medicine, Cornell University, Ithaca, NY, USA

Rajala-Schultz PJ, Gröhn YT, Allore HG: Optimizing breeding decisions for Finnish dairy herds. Acta vet. scand. 2000, 41, 199-212. - The purpose of this study was to determine the effect of reproductive performance on profitability and optimal breeding decisions for Finnish dairy herds. We used a dynamic programming model to optimize dairy cow insemination and replacement decisions. This optimization model maximizes the expected net revenues from a given cow and her replacements over a decision horizon. Input values and prices reflecting the situation in 1998 in Finland were used in the study.

Reproductive performance was reflected in the model by overall pregnancy rate, which was a function of heat detection and conception rate. Seasonality was included in conception rate. The base run had a pregnancy rate of 0.49 (both heat detection and conception rate of 0.7). Different scenarios were modeled by changing levels of conception rate, heat detection, and seasonality in fertility.

Reproductive performance had a considerable impact on profitability of a herd; good heat detection and conception rates provided an opportunity for management control. When heat detection rate decreased from 0.7 to 0.5 , and everything else was held constant, net revenues decreased approximately $2.6 \%$. If the conception rate also decreased to 0.5 (resulting in a pregnancy rate of 0.25 ), net revenues were approximately $5 \%$ lower than with a pregnancy rate of 0.49 . With lower fertility, replacement percentage was higher and the financial losses were mainly from higher replacement costs.

Under Finnish conditions, it is not optimal to start breeding cows calving in spring and early summer immediately after the voluntary waiting period. Instead, it is preferable to allow the calving interval to lengthen for these cows so that their next calving is in the fall. However, cows calving in the fall should be bred immediately after the voluntary waiting period. Across all scenarios, optimal solutions predicted most calvings should occur in fall and the most profitable time to bring a replacement heifer into a herd was in the fall. It was economically justifiable to keep breeding high producing cows longer than low producing cows.

Dynamic programming; reproductive performance; dairy cows; economics.

\section{Introduction}

We used a dynamic programming model, described by McCullough (1992) and McCullough \& DeLorenzo (1996a, b), in our previous study to determine the structure of "an optimal herd" in Finnish conditions (Rajala-Schultz et al. 2000). In that study we found that seasonal milk pricing was an influential factor in optimal insemination and replacement decisions for Finnish herds. The calving interval resulting from the optimal replacement and breeding de- 
Table 1. Finnish input values used in the base run; prices $^{1}$ reflect the situation in 1998 .

\begin{tabular}{|c|c|}
\hline Inputs & Value \\
\hline Average milk yield, $\mathrm{kg}$ & 7711 \\
\hline Average fat $(\%)$ & 4.3 \\
\hline Average protein $(\%)$ & 3.3 \\
\hline Heat detection rate & 0.7 \\
\hline Conception rate & 0.7 \\
\hline Body weight of a cow, $\mathrm{kg}$, parity 1 & 500 \\
\hline parity 2 & 544 \\
\hline parity $3+$ & 590 \\
\hline Calf mortality, parity 1 & 5 \\
\hline parity 2 & 2 \\
\hline parity $3+$ & 2 \\
\hline Calf birth weight, $\mathrm{kg}$, parity 1 & 36 \\
\hline parity 2 & 38 \\
\hline parity $3+$ & 39 \\
\hline Milk price $^{2}, \mathrm{FIM} / \mathrm{kg}$ (without subsidies) & 1.66 \\
\hline Milk price with subsidies 3 , FIM/kg & 2.16 \\
\hline Fat price, FIM/kg (above $4.3 \%$ ) & 0.0124 \\
\hline Protein price, FIM/kg (above 3.3\%) & 0.04 \\
\hline Carcass price, FIM/kg (cow) & 10.76 \\
\hline Price of a replacement heifer, FIM & 7000 \\
\hline Average calf price, FIM $/ 60 \mathrm{~kg}$ calf & 600 \\
\hline Feed cost, FIM $/ \mathrm{kg} / \mathrm{dm}^{4}$ & \\
\hline (low/med producers) & 1.23 \\
\hline Feed cost, FIM/kg/dm (high producers) & 1.33 \\
\hline
\end{tabular}

1 Mälkiä 1999, pers. comm.

${ }^{2}$ Based on $4.3 \%$ fat and $3.3 \%$ protein content, price is from April to June 1998, when the price was lowest (indices for seasonality are given in Table 2.)

${ }^{3}$ Government subsidies vary according to geographical region; a rough overall figure of $0.50 \mathrm{FIM} / \mathrm{l}$ was used in the computations.

${ }^{4}$ Dry matter

cisions across all parities over a 60-month decision horizon was 363 days; however, there was considerable seasonal variation within parity, depending on the month of calving. It was optimal to have most calvings in the fall, and to keep the calving interval of these cows at approximately one year. Hence, cows should be bred from November to February.

Reproductive inefficiency reduces milk produced per cow per day and number of calves born. It also increases the cost of semen and labor expended and may increase the cost of veterinary service and therapy; it also affects rate of culling (Radostits et al. 1994). Thus, reproductive performance can have a significant effect on the profitability of a dairy herd (Britt 1985, Dijkhuizen et al, 1985a).

The purpose of this study was to determine how variation in fertility parameters affects economically optimal breeding recommendations; whether the optimal calving patterns would change with various fertility values. Furthermore, we wanted to develop general guidelines for breeding decisions that would maximize net revenues for Finnish dairy herds.

\section{Materials and methods}

A dynamic programming (DP) model developed for dairy cattle insemination and replacement decisions with Finnish input values was used in this study. The model has been described by McCullough (1992) and McCullough \& DeLorenzo (1996a), who continued the work of Van Arendonk $(1985,1986)$ and Van Arendonk \& Dijkhuizen (1985), who developed the model for Dutch conditions. The Finnish input values and prices reflecting the situation in 1998 that were used in this study are in Table 1. The objective function of the DP model maximizes the expected net present value from current and replacement cows over a given decision horizon (which was 60 months in this study). The decision horizon is divided into 1month long stages and a decision is required at each stage; those decisions are either 1) to keep and not inseminate, 2) to keep and inseminate, or 3) to replace a cow. If the net present value of a cow at a certain stage is lower than that of a replacement heifer over the decision horizon, a decision to replace her should be made. Similarly, if the net present value from a cow leaving her open at a certain stage is lower than breeding her immediately, a decision should be made 
Table 2. Seasonal indices for milk price (government subsidies included) and conception rate (the base values, indicated with index $=1$, are from Table 1 ).

\begin{tabular}{llccc}
\hline \multirow{2}{*}{ Month } & Milk price $^{1}$ & \multicolumn{3}{c}{ Conception rate } \\
\cline { 3 - 5 } & & Base run $^{2}$ & Scenario 3 & Scenario 4 \\
\hline January & 1.12 & 1 & 1 & 1 \\
February & 1.12 & 0.8 & 1 & 0.7 \\
March & 1.03 & 0.8 & 1 & 0.7 \\
April & 1 & 1 & 1 & 1 \\
May & 1 & 1 & 1 & 1 \\
June & 1 & 1.2 & 1 & 1.3 \\
July & 1.06 & 1.2 & 1 & 1.3 \\
August & 1.15 & 1.2 & 1 & 1.3 \\
September & 1.18 & 1 & 1 & 1 \\
October & 1.18 & 1 & 1 & 1 \\
November & 1.18 & 1 & 1 & 1 \\
December & 1.18 & 1 & 1 & \\
\hline
\end{tabular}

${ }^{1}$ Mälkiä (1999, pers. comm.) ${ }^{2}$ Taponen (1999, pers. comm.).

to breed her. The decision to breed a cow has an insemination value (Van Arendonk 1988) which is the extra expected future profit from inseminating a cow, compared to leaving her open for at least 1 month more, taking into account the probability of conception and involuntary disposal.

In the DP, 5 state variables are used to describe each cow, namely lactation number (parity), days open class (i.e., the month of conception during the breeding period), month of lactation, milk production level, and month of calving. A vector of state variable values, $\mathbf{x}_{\mathfrak{t}}$, specifies a single state, such as:

$$
\begin{aligned}
& \mathbf{x}=\left[\mathrm{i}_{\mathrm{t}}, \mathrm{j}_{\mathrm{t}}, \mathrm{k}_{\mathrm{t}}, \mathrm{l}_{\mathrm{t}}, \mathrm{m}_{\mathrm{t}}\right], \\
& \text { where } \mathrm{i}= \text { parity }(\mathrm{i}=1, \ldots ., 12) \\
& \mathrm{j}= \text { conception in month } \mathrm{j} \text { of the } \\
& \text { breeding period }(\mathrm{j}=1, \ldots ., 10), \\
& \text { when } \mathrm{j}=10, \text { denotes open (i.e., } \\
& \text { not pregnant) } \\
& \mathrm{k}= \text { month of lactation }(\mathrm{k}=1, \ldots ., 19) \\
& \mathrm{l}= \text { production level }(\mathrm{l}=1, \ldots ., 5) \text { and } \\
& \mathrm{m}= \text { month of calving }(\mathrm{m}=1, \ldots ., 12) \\
& \text { and } \mathrm{t} \text { denotes stage } \mathrm{t} .
\end{aligned}
$$

For all cow states, milk production based on Finnish lactation curves, feed costs based on energy requirements at a given production level, gross income, total costs and net revenues are calculated. Expected net returns are computed over all possible states and each possible state is weighted by its probability of occurrence. The objective is to maximize the expected net present value of a cow over a 60 month decision horizon. A time value of money was considered and a discounting factor of $0.95 /$ year was used.

The model assumes immediate replacement, so that herd size remains constant. No voluntary replacements occurred within the first 2 months of lactation; therefore, replacements are forced and due to death in this period. The model imposed a 60 -d voluntary waiting period after calving before breeding of cows begins. Replacement heifers (whether home-raised or purchased) enter the model at calving and have an average production level. Replacement heifers are assumed to be available whenever a replacement decision occurs. An annual genetic improvement of approximately $1 \%$ was included. 


\section{Scenarios}

The input values for the base run are in Table 1; the prices reflected the situation in Finland in 1998. We ran 4 different scenarios in addition to the base run by changing the input values for fertility. In Scenario 1, overall fertility (pregnancy rate) was higher ( 0.64 ; both heat detection and conception rate assumed to be 0.8$)$ and in Scenario 2 it was lower $(0.25$; heat detection and conception rate 0.5$)$ than in the base run (0.49); in both of these scenarios fertility was seasonal. In Scenario 3, seasonal fertility was ignored and pregnancy rate was assumed to be constant over the whole year (0.49). In Scenario 4 , seasonal effects on fertility were more profound, i.e., conception in February and March was $12.5 \%$ lower and cows were $8 \%$ more likely to conceive in the summer months than they were during those same periods in the base run (Table 2).

Efficient heat detection is an important part of reproductive management and is under the direct control of the farmer. Thus, to estimate the effect of only changing the heat detection rate, 2 additional runs were performed with lower heat detection rates $(0.5$ and 0.6$)$ and one run with a higher heat detection rate $(0.8)$ than in the base run (0.7); everything else was kept constant.

\section{Results}

\section{Effect of reproductive performance on net} revenues

Overall reproductive performance had a considerable effect on net revenues of a herd. The difference in average net revenues per cow per year between Scenarios 1 (high pregnancy rate) and 2 (low pregnancy rate) was approximately $7 \%$, with everything else kept equal. Net revenues per cow were lower when fertility was lower. The difference in the average net revenues per cow per year between Scenario 2 and the base run was approximately $5 \%$; revenues were reduced with a lower pregnancy rate. When seasonality in conception rate varied (Scenarios 3 and 4), the net revenues changed only slightly (less than $1 \%$ ) from the base run. When heat detection rate decreased from 0.7 to 0.6 (everything else constant), net revenues went down by $1.5 \%$ and if it decreased even more (to 0.5 ), net revenues were about $2.6 \%$ lower than in the base run with heat detection of 0.7 . When heat detection rate increased to 0.8 , net revenues increased approximately $1 \%$ when compared to the base run solution. As reproductive performance decreased, total replacement costs increased.

In Scenarios 1 and 3 (high pregnancy rate and no seasonal variation in reproductive performance, respectively), it was most profitable to bring a new replacement heifer into a herd in December, considering her expected net present value over the whole decision horizon. That was also the case with no seasonal variation in milk pricing (Rajala-Schultz et al. 2000). In Scenarios 2 and 4, as well as in the base run, September was the economically optimal time to have a new replacement heifer calve in a herd. In all scenarios, it was least profitable to bring a new replacement heifer into a herd in May.

\section{Distribution of calvings and replacements}

In the base run's optimal solution, where the pregnancy rate and seasonality in fertility reflected observations in Finland (Jukola et al. 1996, Taponen 1999), most calvings concentrated in August, September and October (Rajala-Schultz et al. 2000). When the pregnancy rate was higher (Scenario 1), the calving distribution was identical to that in the base run. With a lower pregnancy rate (Scenario 2), calvings were the most evenly distributed over the calendar year in the optimal solution, but still concentrated in the late summer and early fall (Fig. 1). In the optimal solution for Scenario 3 


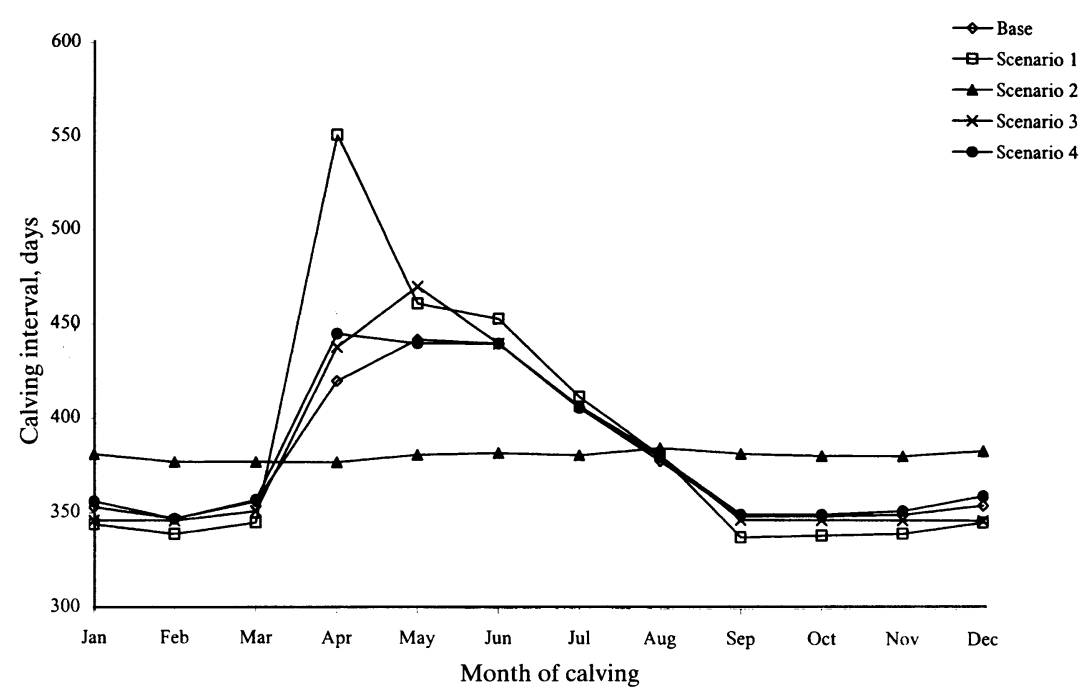

Figure 3 . The length of average calving interval in days by the month of calving in the optimal solution from 5 different scenarios (Base run, pregnancy rate 0.49 ; Scenario 1, pregnancy rate 0.64 ; Scenario 2, pregnancy rate 0.25 : Scenario 3, no seasonality in fertility; Scenario 4, more profound seasonality in pregnancy as in the base run, see Table 2.)

(no seasonality in fertility) and Scenario 4 (more profound seasonal effects on fertility) the distribution of calvings followed the same pattern as in the base run.

In Scenario 1 (high pregnancy rate), total replacement percentage was slightly lower $(25 \%$ versus $26 \%$, respectively) than in the base run and there was a peak in replacement distribution in December (in the base run it was in September). With a lower pregnancy rate (Scenario 2 ), total replacement percentage was higher $(31 \%)$ than in the base run and more replacements occurred in August and September than in the base run (Fig. 2). None of the culling occurring during February through July was voluntary in any scenario. Most voluntarily replaced cows calved in March through July and were removed on average 162 to 202 days after calving, i.e., in September through December. When seasonality in fertility was ignored (Sce- nario 3), there were 2 peaks in replacements, in September and December, but total replacement percentage was the same as in the base run. In Scenario 4, the replacement distribution followed the same pattern as in the base run (Fig. 2).

The average herdlife (in moths from the first calving) in the optimal solution from Scenario 2 was 43.0 months, while in the base run's optimal solution it was 48.2 months and in Scenario 1 it was 48.6 months.

With a high pregnancy rate (Scenario 1), the calving interval varied considerably depending on month of calving, being longest in April, May and June (Fig. 3). The peak in the length of an average calving interval in the base run and in Scenarios 3 and 4 was more moderate. In Scenario 2 (low pregnancy rate), the average calving interval was 381 days, with only $+/-4$ day variation between months of calving (Fig. 


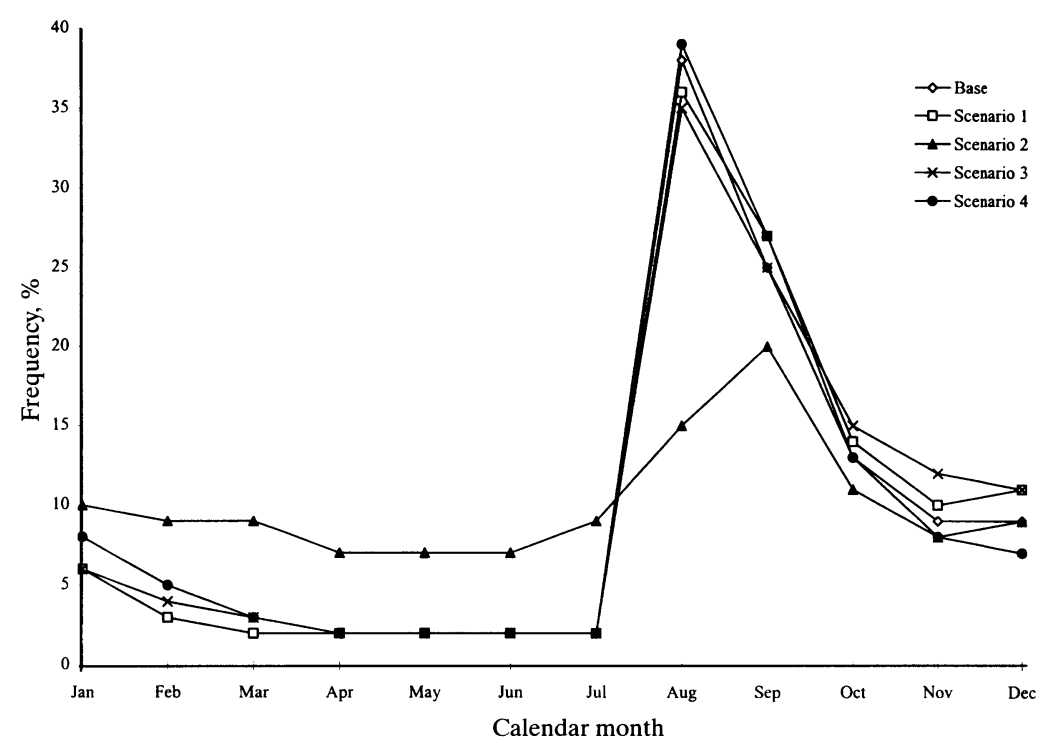

Figure 1. Distribution of calvings by calendar month in the optimal solution from 5 different scenarios (Base run, pregnancy rate 0.49 ; Scenario 1 , pregnancy rate 0.64 ; Scenario 2 , pregnancy rate 0.25 : Scenario 3 , no seasonality in fertility; Scenario 4 , more profound seasonality in pregnancy as in the base run, see Table 2.)

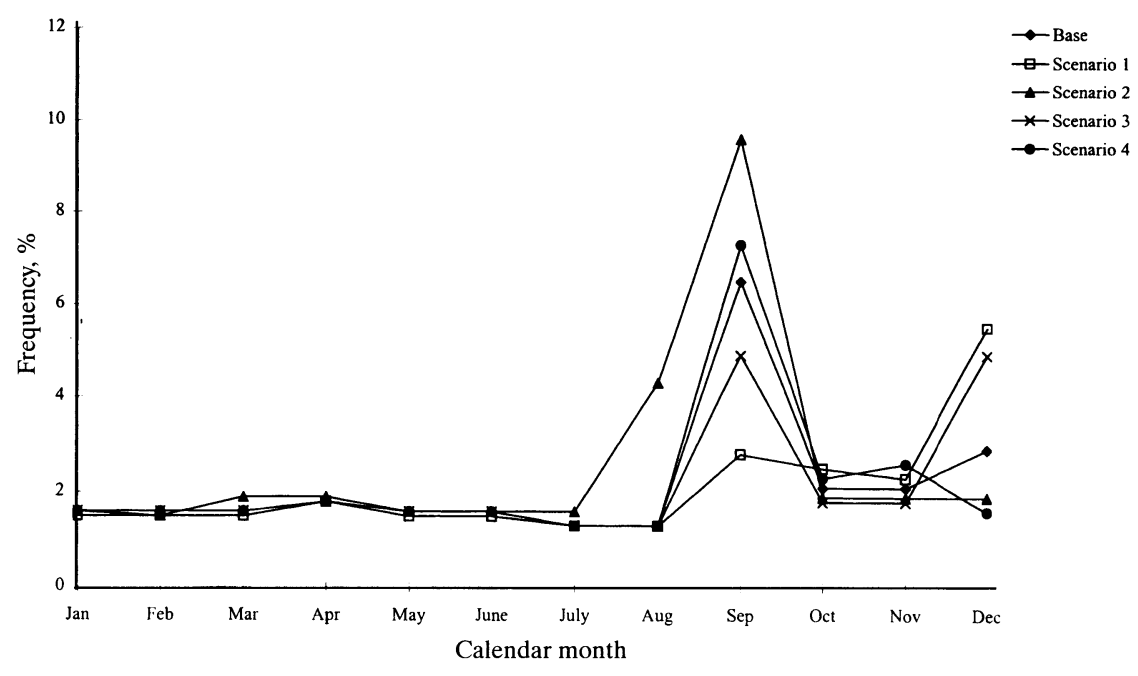

Figure 2. Distribution of replacements (frequency as a portion of a herd) by calendar month in the optimal solution from 5 different scenarios: Base run, pregnancy rate 0.49 ; Scenario 1 , pregnancy rate 0.64 ; Scenario 2 , pregnancy rate 0.25 : Scenario 3 , no seasonality in fertility; Scenario 4 , more profound seasonality in pregnancy as in the base run, see Table 2.) 
3). The average length of a calving interval resulting from an optimal policy over the decision horizon (60 months) decreased with improving reproductive performance (in the base run solution, the average calving interval was 363 days and in Scenario 1 it was 358 days).

\section{Breeding recommendations}

In the base run's optimal solution it was optimal to postpone breeding and leave the cow open in $39.5 \%$ of all possible stages. With a higher pregnancy rate the percentage was 50.5 and with a lower pregnancy rate it was only 14.4. Thus, Scenario 1 (a high pregnancy rate) allowed choosing the time to breed or not to breed cows, i.e., to postpone breeding intentionally. There was a considerable variation in the proportion of decisions made not-to-breed between different months of calving, except for Scenario 2 (low pregnancy rate). With the highest pregnancy rate, most decisions not-to-breed were made, based on the month of calving, in the beginning of the year, especially in March and April. Cows that calve in April would first be bred in June (after the 60-day voluntary waiting period) and if they conceived during the summer months, they would then calve again in early spring and thus they would be at their peak production in April-May, when the milk price is the lowest. Except for Scenario 2, the fewest decisions not-to-breed were made with cows calving in late summer and fall. With poor reproductive performance, it was optimal to inseminate a cow at most observable heats.

The breeding recommendations based on the optimal solution from the base run varied considerably depending on the month of calving. It was optimal to start breeding cows that calved during fall and winter (September through February) immediately after the end of the voluntary waiting period. However, for cows that calved in spring and summer (March through August) it was, in some cases, optimal to wait even 5 months after calving before starting to breed them, or not to breed them at all; instead, it was optimal to replace them (this was true especially for lowest producing cows in parity 1) (Figs. 4A and 4B).

Even when seasonality in fertility was ignored or when it was assumed to be more profound than in the base run, the breeding recommendations followed the same basic pattern as in the solution from the base run. It was economically optimal to postpone breeding cows calving in April through August by several months to avoid having them calve again in spring. This was the case even when breeding would coincide with the least likely time of conception (February and March).

\section{Effect of parity and milk production on breeding recommendations}

Regardless of the scenario (i.e., the values of fertility parameters), it was optimal to breed the lowest producers for much shorter time than the highest producers. Figs. 4A and 4B illustrate the insemination values (extra future profits from breeding a cow "now" versus leaving her open for at least 1 more month) by month of calving and month of breeding from the base run's optimal solution. In the base run, if a cow was in the lowest quintile $(20 \%)$ with respect to her milk production level, the value of breeding her was much lower and it was worth inseminating her fewer times than if she was among the highest producers. This was true especially if she was in her first parity. If a cow calved during fall or winter (September through February), it was optimal to start inseminating her after the voluntary waiting period and there was a financial incentive, in most cases, to breed her at least 3 or 4 times, even if she was a low producer (Figs. 4A and 4B). It was optimal to keep breeding the highest producers that calved during the fall up to 11 months in lactation (i.e., corresponding to a calving interval of 19 

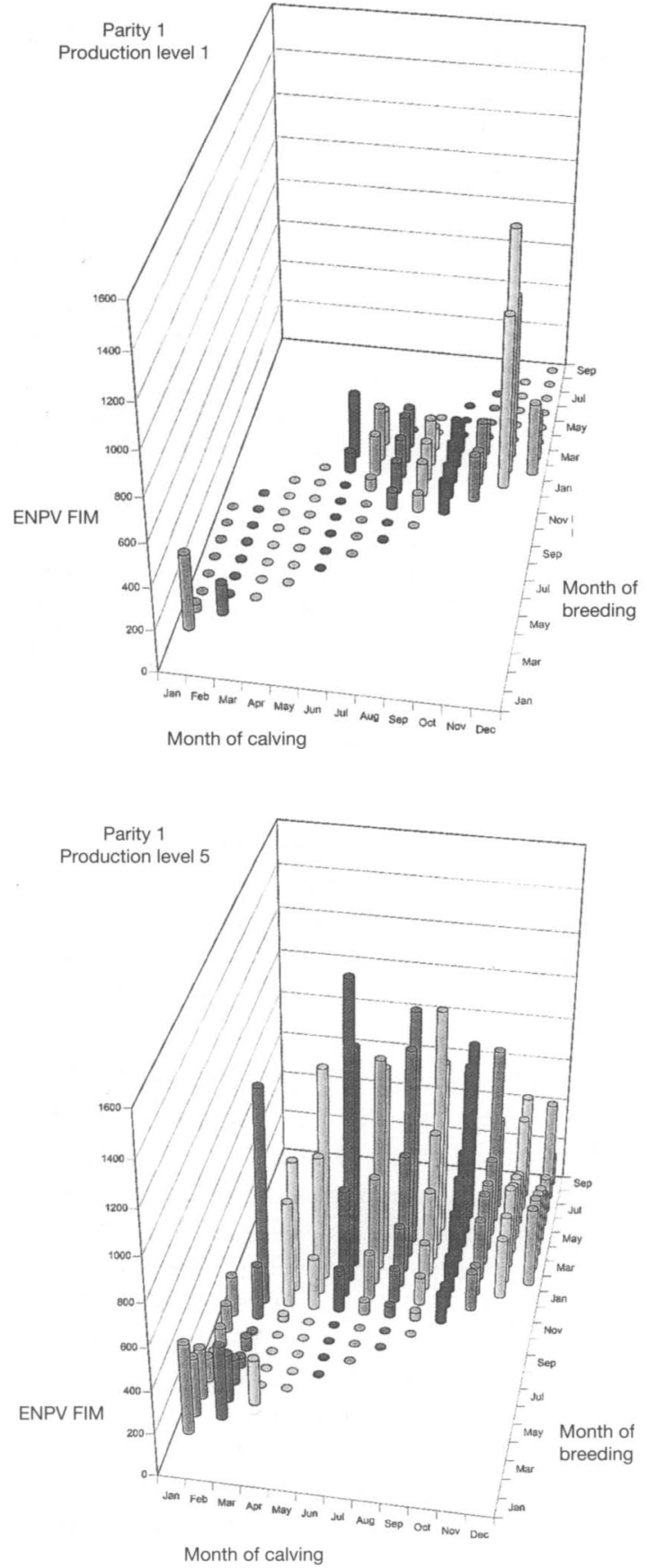

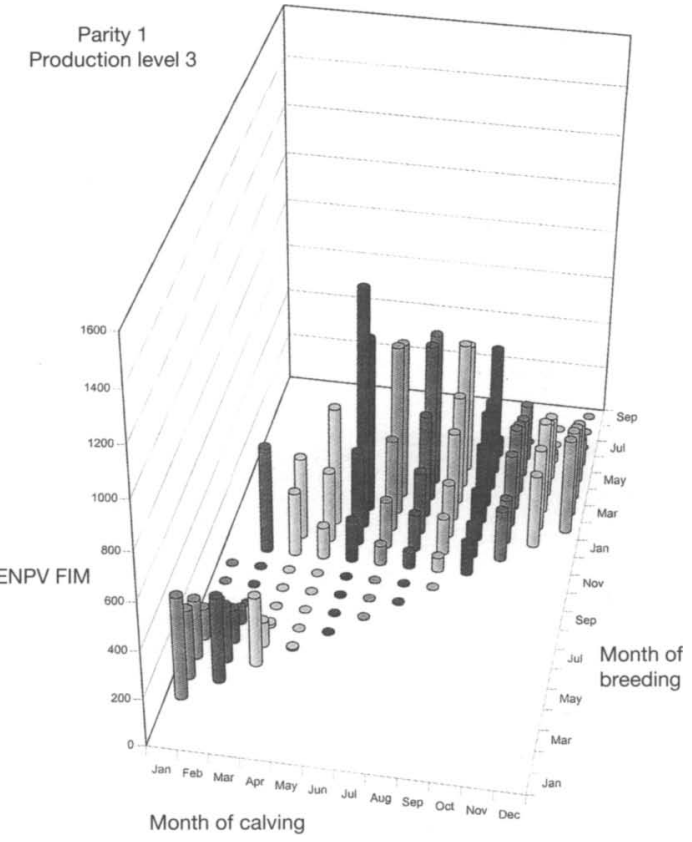

Figure 4. Insemination values of cows in parity 1 (Fig. 4A) and in parity 3 (Fig. 4B) with different milk production levels by month of calving and month of breeding. Values are from the base run's optimal solution and they represent the expected net present value (ENPV, in FIM) of breeding a cow at a certain time versus leaving her open for at least another month. The model assumes 60 -day voluntary waiting period and breeding is allowed for nine months (the values for last breeding month are not shown in the figure, because they reflect the forced decision of culling versus breeding at the end of the breeding period and thus are inflated artificially). 

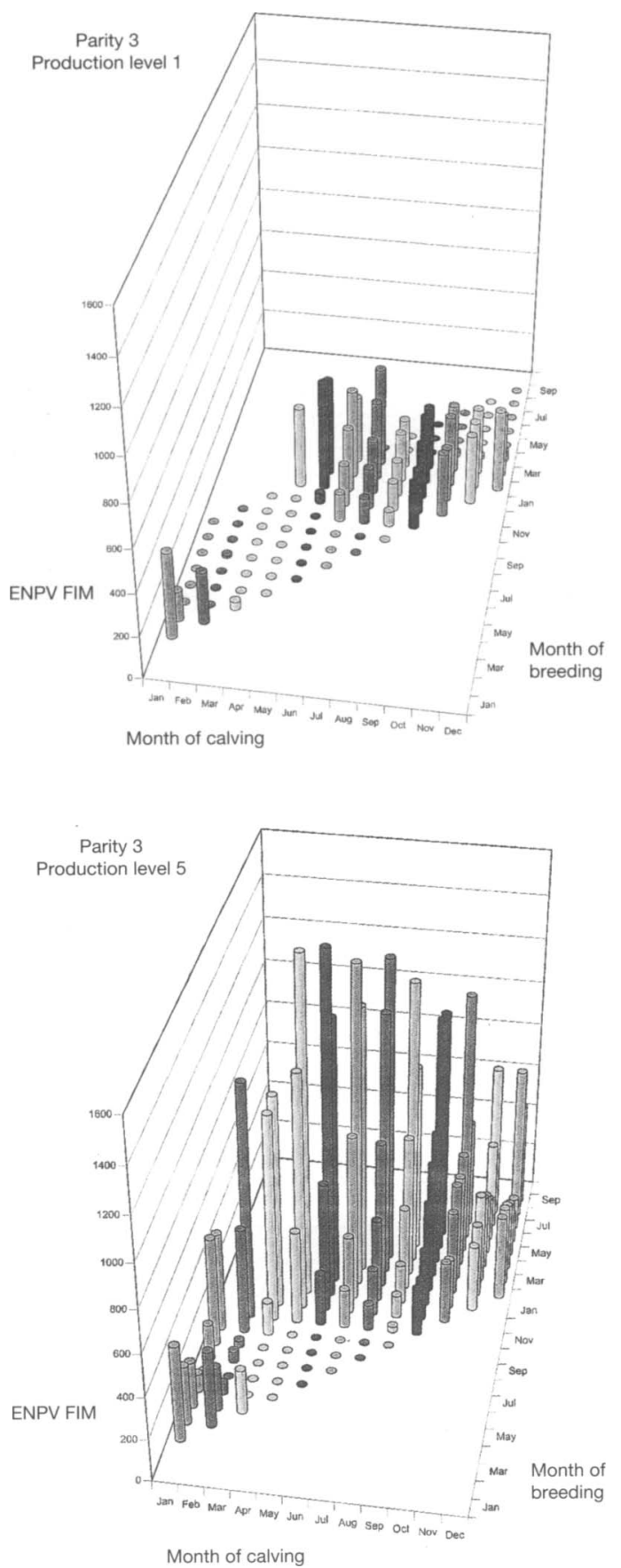

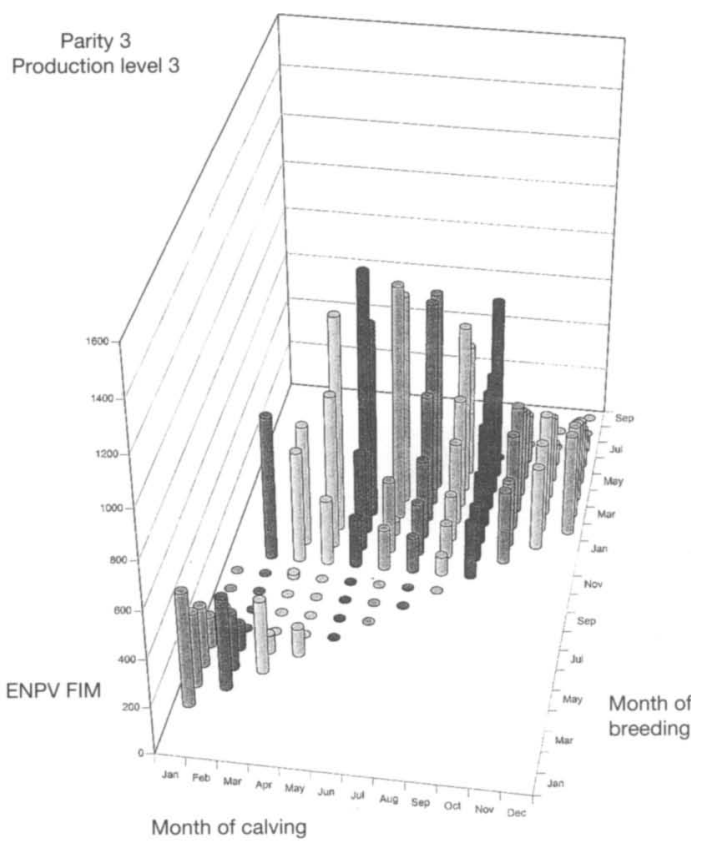

months, which was the maximum length for a calving interval that the model allowed). Figs. 4A and 4B also clearly show that it was not optimal to breed cows between July and October, regardless of parity and production level of a cow.

With a high pregnancy rate it was optimal to breed for a shorter and selected period, for both the lowest and the highest producers. It was optimal to breed the cows so that they would not be calving during the spring and early summer. With a high pregnancy rate, the next calving was planned to occur during a shorter period (September and October) than in any other scenarios. If the reproductive performance of a herd was low (Scenario 2), it was not economically justifiable to try to breed first parity cows in the lowest production quintile that calved during spring at all. In general, older cows could be bred more times than cows in parity 1 . A cow moving up one production level to the 


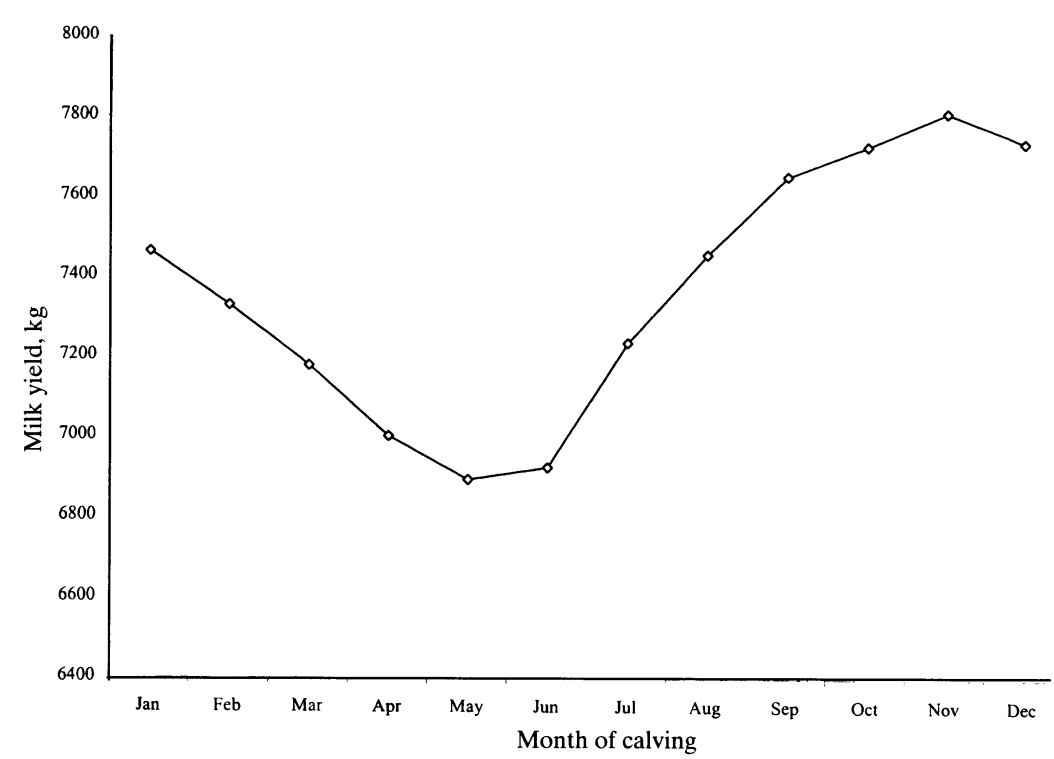

Figure 5. 305-day milk production (kg) of Finnish Ayrshire cows by month of calving (Rajala-Schultz 1999, unpublished data).

next quintile usually justified one more attempt at breeding her. This was true especially with cows calving during the fall.

\section{Discussion}

Reproductive performance of a dairy herd affects several traits that directly or indirectly affect the profits of a farm (Britt 1985). Dijkhuizen et al. (1985a) estimated that total loss due to reproductive failure averaged about $2 \%$ of the gross production value per cow per year in Dutch conditions. These losses resulted mainly from suboptimal calving interval and forced replacements. We observed that the rate of culling and total replacement costs increased with lower reproductive performance, and that the average amount of milk produced per cow per year decreased. Overall, net revenues were less with lower reproductive performance in a herd. In our study the difference in average net revenues per cow per year between the base sce- nario (pregnancy rate of 0.49 ) and Scenario 2 (pregnancy rate of 0.25 ) was approximately $5 \%$, the losses resulting mainly from increased replacement costs.

With all the scenarios, calving and replacement distributions looked quite similar. Studies have indicated that the calving interval for optimal milk production and profit lies between 12 and 13 months (Strandberg \& Oltenacu 1989, Dijkhuizen et al. 1985a). Our results, however, showed that the calving interval resulting from optimal breeding and culling decisions (aimed at maximizing net revenues) could vary considerably between different calving months.

According to the optimal policy in the findings of Houben et al. (1994) cows were inseminated immediately after the voluntary waiting period and only the lowest producing cows were left open in some cases. Our breeding recommendations aimed at having cows calving in fall and at the very beginning of a year. One reason for 
this is the fact that milk prices are highest from September to December and only slightly lower in January and February. However, even without seasonality in milk pricing, calvings still concentrated from September to January ( $R a$ jala-Schultz et al. 2000). In Finland, the overall production of cows calving in fall has been observed to be higher than the yield of cows calving at any other time of the year (Rajala \& Gröhn 1998b). In fact, the 305-d yield is lowest for cows calving in May, increases gradually, and is highest among cows calving in November, after which it declines again to the low of May (Fig. 5); the difference in the overall lactational milk yield of Finnish Ayrshire cows calving in May and November in 1993 was over 900 $\mathrm{kg}$ (Rajala-Schultz 1999, unpublished data). This also explains why most voluntarily replaced cows in the optimal solution in this study were cows which calved between March and July. Also, Strandberg \& Oltenacu (1989) reported that autumn calvers in Sweden gave substantially higher net returns per year than cows calving from November to April; the reasons for that were seasonal variations in milk price and high production of autumn calvers.

Observing cows in estrus and inseminating them at the optimal time are necessary steps for effective reproductive management of a dairy herd (Nebel \& Jobst 1998). Britt (1985) reported that there appears to be a direct relationship between herd management and reproductive performance and thus, reproductive performance and profit respond positively to improvements of rates of estrus detection and conception and to improvements of management of periparturient cows. Our results agree with that, as we observed that with decreasing heat detection rate, net revenues in the optimal solution also decreased. Low pregnancy rate did not allow for much selective insemination, whereas better heat detection and higher conception rate provided an opportunity for man- agement control. This agrees with the results of McCullough \& DeLorenzo (1996b). However, at high latitudes, such as in Finland, seasonal variation is very marked by the length of daylight, i.e., a short period of daylight during the winter and long days and short nights in the summer. Earlier studies on Finnish Ayrshire dairy cows have shown that cows calving during the dark seasons (fall and winter) are more likely to be treated for fertility disorders (silent heat, ovarian cysts and other fertility disorders) than cows calving during the light seasons (Gröhn et al. 1990, Gröhn et al. 1994, Harman 1994, Rajala \& Gröhn 1998a). Harman et al. (1996) reported that the effect of season on the parturition-to-conception interval was considerable between the latitudes where Finland is located; parturition during late April, causing confluence of post partum day 55 with summer solstice, was associated with the shortest parturition-to-conception intervals. Thus, it is not necessarily easy to reach the recommended calving distribution. Our results suggest that farmers could invest up to $2.6 \%$ of net revenues per cow to improve heat detection rate from 0.5 to 0.7 ; a further improvement from 0.7 to 0.8 in heat detection is worth $1 \%$ increase in net revenues. Ways farmers could improve reproductive performance are by investing more time observing signs of estrus, using prostaglandin for synchronizing estrous cycles and in high latitudes, like in Finland, improving lighting in the barn. Reksen et al. (1999) concluded from their study in Norway that dairy cattle kept at high latitudes during winter should be exposed to dim illumination at night and a minimum photoperiod of $12 \mathrm{~h}$ to stimulate reproductive performance. Figs. 4A and 4B illustrate how much could be spent on management interventions per cow to improve reproductive performance. Results from this study indicated that it is economically justifiable to try breeding higher producing cows longer than low producing cows, 
which agrees with the results and guidelines of Dijkhuizen et al. (1985b) and Dohoo \& Dijkhuizen (1993). It also agrees with results from several observational studies where low producers have been observed to be more likely to be culled than high producers (Dohoo \& Martin 1984, Oltenacu et al. 1984, Beaudeau et al. 1995, Gröhn et al. 1998, Rajala-Schultz \& Gröhn 1999). Dijkhuizen et al. (1985b) reported that persistence of milk production during lactation and recurring fertility problems have a considerable influence on how long it is profitable to continue inseminating a cow.

The results obtained in this study represent "an average herd" in Finland, but circumstances in individual herds, as well as characteristics of individual cows, can vary considerably. Thus, all aspects of the results may not apply to all herds. Also, computer models are always simplifications of the real world. Despite the assumptions and limitations of the model which have been described and discussed earlier (Rajala-Schultz et al. 2000), we believe that the results from all the different scenarios evaluated in this and in our previous study (Rajala-Schultz et al. 2000) provide enough evidence to state that in Finland it is optimal to try to have calvings concentrate in the fall and that even with a low pregnancy rate it is justifiable to postpone breeding cows calving in the spring by several months. This is driven by seasonal milk pricing and higher lactational milk production of fall calvers. However, if an individual cow is known to have low persistence of milk production or if she has a history of recurring fertility problems, it is probably not profitable to keep breeding her as long as a cow with good persistence. Hence, it might not be economically optimal to breed a cow that calved in April and is not among the highest producers in the herd.

Some of the limitations and assumptions of the model, discussed in Rajala-Schultz et al. (2000), are worth mentioning again. The model assumes immediate replacement and availability of heifers whenever a replacement is recommended. The assumption about having heifers available might not always hold in Finland, where most heifers are raised on the home farm. Also, the model does not take into account an interaction between milk production and fertility. However, Eicker et al. (1996) concluded that increased milk production has a very minor effect on conception rates of dairy cows, so we believe that this would not affect the results. Besides, the model provides different breeding recommendations for cows in different parities and production levels (Figs. 4A and B). The lack of disease effects in the model on fertility was also discussed in the previous paper (Rajala-Schultz et al. 2000). Despite any limitations of the model, it is clear from the results that with efficient reproductive management it is possible to improve profitability of a dairy herd.

The model used in this study solves for an optimum; however, most current Finnish herds can not change immediately to the optimal structure. The results derived from this study provide practical guidelines to assist farmers in making more profitable management decisions. By paying careful attention to reproductive management and improving heat detection efficiency and accuracy, it is possible to increase net revenues of a farm. Farmers should also attempt to have more calvings concentrate in the fall, as fall calvers produce more and milk prices are higher in the fall and winter.

\section{Acknowledgements}

This study was supported by the Finnish Academy (Helsinki, Finland). 


\section{References}

Beaudeau F, Ducrocq V, Fourichon C, Seegers H: Effect of disease on length of productive life of French Holstein dairy cows assessed by survival analysis. J. Dairy Sci. 1995, 78, 103-117.

Britt JH: Enhanced reproduction and its economic implications. J. Dairy Sci. 1985, 68, 1585-1592.

Dijkhuizen AA, Renkema JA, Stelwagen J: Economic aspects of reproductive failure in dairy cattle. I. Financial loss at farm level. Prev.Vet.Med. 1985a, 3, 251-263.

Dijkhuizen AA, Renkema JA, Stelwagen J: Economic aspects of reproductive failure in dairy cattle. II. The decision to replace animals. Prev. Vet. Med. 1985b, 3, 265-276.

Dohoo IR, Dijkhuizen AA: Techniques involved in making dairy cow culling decisions. Comp. Cont. Edu: 1993, 515.

Dohoo IR, Martin SW: Disease, production and culling in Holstein-Friesian cows. V. Survivorship. Prev. Vet. Med. 1984, 2, 771-784.

Eicker, SW, Gröhn YT, Hertl JA: The association between cumulative milk yield, days open, and days to first breeding in New York Holstein Cows. J. Dairy Sci. 1996, 79: 235-241.

Gröhn YT, Eicker SW, Ducrocq V, Hertl JA: Effect of diseases on culling in New York State Holstein Dairy Cows. J. Dairy Sci 1998, 81, 966-978.

Gröhn YT, Erb HN, McCulloch CE, Saloniemi HS: Epidemiology of Reproductive Disorders in dairy cattle: Associations Among Host Characteristics, Disease and Production. Prev. Vet. Med. 1990, 8, 25-39.

Gröhn YT, Hertl JA, Harman JL: Effect of early lactation milk yield on reproductive disorders in dairy cows. Am. J. Vet. Res. 1994, 55, 15211528.

Harman JL: The effect of early lactation milk yield on dairy cow interval-to-conception: a survival analysis. Ph.D. dissertation, Cornell University, College of Veterinary Medicine, Department of Clinical Sciences, Ithaca, NY, USA., 1994, p.164.

Harman, JL, Gröhn YT, Erb HN, Casella G: Eventtime analysis of the effect of season of parturition, parity, and concurrent disease on parturition-to-conception interval in dairy cows. Am. J. Vet. Res. 1996, 57, 640-645.

Houben EHP, Huirne RBM, Dijkhuizen AA, Kristensen AR: Optimal replacement of mastitic cows determined by a hierarchic Markov process. J. Dairy Sci. 1994, 77, 2975-2993.
Jukola E, Hakkarainen J, Saloniemi H, Sankari S: Blood selenium, vitamin E, Vitamin A, and betacarotene concentrations and udder health, fertility treatments, and fertility. J. Dairy Sci. 1996, 79, 838-845.

Mälkiä P: Personal communication, The Association of Rural Advisory Centres, Helsinki, Finland, 1999.

McCullough DA: Effects of model specifications and exogenous variables on a stochastic dynamic insemination and replacement model for dairy cattle. MS thesis, Univ. Florida, Department of Dairy Science, Gainesville, 1992, p.168.

McCullough DA, DeLorenzo MA: Evaluation of a stochastic dynamic replacement and insemination model for dairy cattle. J. Dairy Sci 1996a, 79, 50-61.

McCullough DA, DeLorenzo MA: Effects of price and management level on optimal replacement and insemination decisions. J. Dairy Sci. 1996b, 79, 242-253.

Nebel RL, Jobst SM: Evaluation of systematic breeding programs for lactating cows: A review. J. Dairy Sci. 1998, 81, 1169-1174.

Oltenacu PA, Britt JH, Braun RK, Mellenberger RW: Effect of Health Status on Culling and Reproductive Performance of Holstein Cows. J Dairy Sci 1984, 67, 1783-1792.

Radostits OM, Leslie KE, Fetrow J: Maintaining reproductive efficiency in dairy cattle. In: Herd health. Food animal production medicine. Philadelphia, W.B. Saunders Company 1994, p. 141158.

Rajala, PJ, Gröhn YT: Disease occurrence and risk factors analysis in Finnish Ayrshire cows. Acta Vet. Scand. 1998a, 39, 1-13.

Rajala PJ, Gröhn YT: Effects of dystocia, retained placenta and metritis on milk yield in Finnish Ayrshire cows. J. Dairy Sci. 1998b, 81, 31723181.

Rajala-Schultz PJ, Gröhn YT: Culling of dairy cows. Part III. Effects of diseases, pregnancy status and milk yield on culling in Finnish Ayrshire cows. Prev. Vet. Med. 1999, 41, 295-309.

Rajala-Schultz PJ, Gröhn YT, Allore HG: Optimizing replacement decisions for Finnish dairy herds. Acta Vet. Scand. 2000, 41, 199-212.

Reksen $O$, Tverdal A, Landsverk K, Kommisrud E, Bøe KE, Ropstad E: Effects of Photointensity and Photoperiod on Milk Yield and Reproductive Performance of Norwegian Red Cattle. J. Dairy Sci. 1999, 82, 810-816. 
Strandberg E, Oltenacu PA: Economic consequences of different calving intervals. Acta Agric. Scand. 1989, 39, 407-420.

Taponen J: Personal communication, University of Helsinki, Faculty of Veterinary Medicine, Helsinki, Finland, 1999.

Van Arendonk, JAM: Studies on the replacement policies in dairy cattle. II. Optimal policy and influence of changes in production and prices. Livest. Prod. Sci. 1985, 13, 101-120.

Van Arendonk, JAM: Studies on the replacement policies in dairy cattle. IV. Influence of seasonal variation performance and prices. Livest. Prod. Sci. 1986, 14, 15-28.

Van Arendonk JAM: Management guides for insemination and replacement decisions. J. Dairy Sci. 1988, 71, 1050-1057.

Van Arendonk, JAM, Dijkhuizen, AA: Studies on the replacement policies in dairy cattle III. Influence of variation in reproduction and production. Livest. Prod. Sci. 1985, 13, 333-349.

\section{Sammanfattning}

Optimering av inseminationstidpunkt för finska mjölkbesättningar.

Meningen med denna studie var att evaluera effekten av reproduktionsresultat på lönsamheten och den optimala inseminationstidpunkten i finska mjölkbesättningar. Vi använde en dynamisk programmeringsmodell, utvecklad för att optimera beslut gällande inseminering och rekrytering av mjölkkor. Denna optimeringsmodell maximerar de väntade totalinkomsterna för en given ko och hennes ersättare över en beslutsperiod. Inputvärden och priser reflekterande den finska situationen år 1998 användes i studien.
Reproduktionsresultatet reflekterades i modellen av totalt dräktighetsresultat, som i modellen var en produkt av brunstdetektion och befruktningsresultat. Årstidseffekter beaktades i befruktningsresultatet. Baskörningen hade dräktighetsresultatet 0.49 (både brunstdetektion och befruktningsresultat var 0.7) och speglar situationen i Finland. Flera olika scenarier iscensattes genom att förändra befruktningsresultat, brunstdetektion och årstidseffekter på fruktbarheten. Reproduktionsresultatet hade en betydande inverkan på besättningens lönsamhet; hög brunstdetektion och högt befruktningsresultat erbjöd möjligheter att kontrollera insemineringstidpunkter och övriga rutiner. När brunstdetektionen sänktes från 0.7 till 0.5 , medan alla andra faktorer hölls konstanta sjönk den totala inkomsten med cirka $2.6 \%$. Om även befruktningsresultatet sjönk till 0.5 (vilket resulterar $\mathrm{i}$ ett totalt dräktighetsresultat på 0.25 ), var den totala inkomsten cirka 5\% lägre än vid ett dräktighetsresultat på 0.49. Med lägre fruktbarhet var rekryteringsprocenten högre och utgifterna ökades främst av högre rekryteringskostnader.

Under finska förhållanden är det inte optimalt att börja seminera kor som kalvat på vår och tidig sommar genast efter den rekommenderade tomperioden; det lönar sig i stället att tillåta en förlängning av kalvningsintervallet så att deras nästa kalvning blir på hösten. Kor som kalvar på hösten borde dock semineras genast efter den rekommenderade tomperioden. I alla de optimala lösningarna skedde de flesta kalvningarna på hösten och den mest lönsamma tiden för introduktion av en rekryteringskviga $\mathrm{i}$ besättningen var på hösten. Det är ekonomiskt befogat att seminera högproducerande kor flera gånger än lågproducerande kor.

(Received June 21, 1999; accepted February 28, 2000).

Reprints may be obtained from: P. J. Rajala-Schultz, Department of Veterinary Preventive Medicine, College of Veterinary Medicine, The Ohio State University, 1900 Coffey Road, Columbus, OH 43210, USA. E-mail: rajalaschultz.1@osu.edu, tel: 614-292-1206, fax: 614-292-4142. 